\title{
The Role of the Dopamine $\beta$-hydroxylase Functional Polymorphism in Patients with Early-Onset Parkinson's Disease in the Turkish Population
}

\author{
Türk Popülasyonundaki Erken Başlangıçı Parkinson Hastalarında Dopamin \\ $\beta$-hidroksilaz Fonksiyonel Polimorfizminin Rolü
}

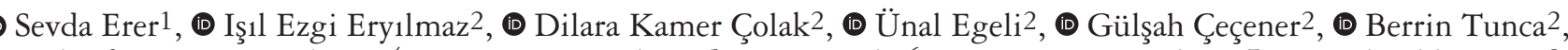

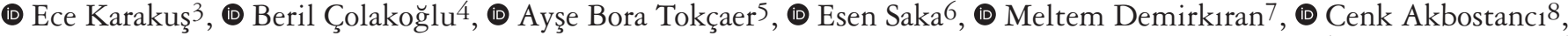

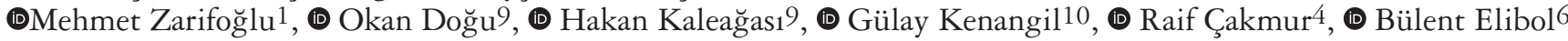

${ }^{1}$ Bursa Uludag University Faculty of Medicine, Department of Neurology, Bursa, Turkey 2Bursa Uludag University Faculty of Medicine, Department of Medical Biology, Bursa, Turkey ${ }^{3}$ Bursa Uludag University Faculty of Medicine, Bursa, Turkey ${ }^{4}$ Dokuz Eylul University Faculty of Medicine, Department of Neurology, Izmir, Turkey

5 Gazi University Faculty of Medicine, Department of Neurology, Ankara, Turkey 6 Hacettepe University Faculty of Medicine, Department of Neurology, Ankara, Turkey ${ }^{7}$ Cukurova University Faculty of Medicine, Department of Neurology, Adana, Turkey ${ }^{8}$ Ankara University Faculty of Medicine, Department of Neurology, Ankara, Turkey 9Mersin University Faculty of Medicine, Department of Neurology, Mersin, Turkey 10Bahcesehir University Goztepe Medical Park, Department of Neurology, Istanbul, Turkey

\begin{abstract}
Objective: A functional single nucleotide polymorphism, rs1611115, in the dopamine $\beta$-hydroxylase (DBH) gene, is reported to regulate plasma enzyme activity levels. Here, we report the first evaluation of this association in patients with early-onset Parkinson's disease (EOPD) and healthy controls in the Turkish population.

Materials and Methods: We evaluated the $D B H$ rs 1611115 polymorphism in 114 (64 male and 50 female) Turkish patients with EOPD and 58 sex- and agematched healthy controls from the Turkish population. A total of $27.2 \%(\mathrm{n}=31)$ of our patients who had any variation including pathogenic or non-pathogenic missense, non-sense and/or intronic variation with unknown significance in EOPD genes were grouped as "variation-positive EOPD". A total of 50.8\% (n=58) of our patients were grouped as "variation and family history-negative EOPD" and the possible contribution of the DBH rs1611115 polymorphism to EOPD pathogenesis was evaluated in this group.

Results: There was no significant difference in the genotypic and allelic frequencies of $D B H$ rs 1611115 between patients with EOPD and controls. To our knowledge, this is the first evaluation of the $D B H$ rs 1611115 polymorphism in patients with EOPD and ethnically matched controls in the Turkish population. Conclusion: Some previous studies have reported conflicting association results between $D B H$ rs 1611115 polymorphism and PD pathogenesis in different ethnic groups. Therefore, further studies are needed to evaluate dopamine metabolism-related genetic variants and to determine their possible roles in EOPD susceptibility in the Turkish population.
\end{abstract}

Keywords: Early-onset Parkinson's disease, dopamine $\beta$-hydroxylase ( $D B H)$, polymorphism, Turkish population

Address for Correspondence/Yazışma Adresi: Sevda Erer MD, Bursa Uludag University Faculty of Medicine, Department of Neurology, Bursa, Turkey Phone: +90 2242951751 E-mail: sevdaerer@gmail.com ORCID: orcid.org/0000-0002-2274-3230

Received/Geliş Tarihi: 21.04.2020 Accepted/Kabul Tarihi: 03.11.2020

${ }^{\circ}$ Copyright 2021 by Turkish Neurological Society

Turkish Journal of Neurology published by Galenos Publishing House. 


\section{$\ddot{O} \mathbf{z}$}

Amaç: Dopamin $\beta$-hidroksilaz $(D B H)$ genindeki fonksiyonel rs1611115 tek nükleotid polimorfizminin enzimin plazma aktivite seviyesini düzenlediği bildirilmektedir. Mevcut çalışmada, Türk popülasyonundaki erken başlangıçlı Parkinson hastalarında (EBPH) ve sağlıklı kontrollerde bu ilişkinin ilk değerlendirmesini sunmaktayız.

Gereç ve Yöntem: Türk popülasyonundan 114 (64 erkek ve 50 kadın) EBPH hastasında ve 58 cinsiyet ve yaş uyumlu sağliklı kontrolde $D B H$ rs1611115 polimorfizmini değerlendirdik. EBPH genlerinde patojenik veya patojenik olmayan yanlış anlamlı, anlamsız ve/veya intronik herhangi bir varyasyona sahip olan hastalarımız (\%27,2; $\mathrm{n}=31)$ "varyasyon pozitif EBPH hastası" olarak gruplandırıldı. Hastalarımızın \%50,8'i (n=58) ise "varyasyon ve aile öyküsü negatif EBPH hastaları" olarak gruplandırıldı ve $D B H$ rs1611115 polimorfizminin EBPH patogenezine olası katkısı bu grupta değerlendirildi.

Bulgular: EBPH hastaları ve sağlıklı kontroller arasında $D B H$ rs1611115 polimorfizminin genotipik ve allelik frekanslarında anlamlı bir fark bulunmadı. Bildiğimiz kadarıyla bu sonuç, Türk popülasyonunda EBPH hastalarında ve etnik olarak eşleştirilmişs sağlıklı kontrollerde $D B H$ rs 1611115 polimorfizminin ilk değerlendirmesidir.

Sonuç: Önceki bazı çalışmalar, farklı etnik gruplarda DBH rs1611115 polimorfizmi ve PH patogenezi arasında çelişkili ilişki sonuçları olduğunu bildirmiştir. Diğer taraftan, Türk popülasyonunda dopamin metabolizması ile ilişkili genetik varyantları de ğerlendirmek ve EBPH duyarlılı̆̆ında olası rollerini belirlemek için daha fazla çalışmaya ihtiyaç vardır.

Anahtar Kelimeler: Erken başlangıçlı Parkinson hastalığı, dopamin $\beta$-hidroksilaz ( $D B H$ ), polimorfizm, Türk popülasyonu

\section{Introduction}

Parkinson's disease (PD) is a neurodegenerative disorder characterized by the selective loss of dopaminergic neurons in the substantia nigra. The motor symptoms of PD appear when dopamine cannot be produced in sufficient amounts due to dopamine-producing cell loss. The prevalence of PD increases after the age of 60 years, and the disease progressively worsens due to continuous age-related degeneration of other brain areas $(1,2,3)$. However, if the patient is aged under 50 years at diagnosis, they are said to have early-onset PD (EOPD). To date, patients with germline genetic and/or epigenetic alterations and copy number variations that contribute to EOPD pathogenesis, especially in the SNCA and PARK2 genes, have been defined as associated with the disease $(4,5,6,7,8)$. However, the majority of Turkish patients with EOPD do not have any mutations in EOPD genes (6). Additionally, dysregulation of any of these genes does not cause changes that directly affect dopamine metabolism, which acts only as a treatment modality of PD due to depleted dopamine levels.

Alterations related to dopamine metabolism including synthesis, conversion, storage, binding, and degradation may be informative both at the onset and during the treatment process of PD. Dopamine $\beta$-hydroxylase $(D B H)$ is a rate-limiting enzyme that is responsible for the conversion of dopamine to noradrenaline (9). In the literature, some single nucleotide polymorphisms (SNPs) in DBH have been reported to change enzyme activity and function. The best known among the SNPs, rs1611115 (-1021C $>\mathrm{T}$ ), is a functional promoter polymorphism in $\mathrm{DBH}$ that causes a change in the amount of dopamine by reducing plasma $\mathrm{DBH}$ activity $(10,11)$. Although the presence of the homozygous $\mathrm{T} / \mathrm{T}$ allele has been reported to protect against PD susceptibility due to low $\mathrm{DBH}$ activity resulting in increased dopamine levels, the existing results remain controversial. Kang et al. (12) suggested that the $D B H$ rs1611115 genetic polymorphism might not be associated with PD in Asia or Europe. However, a recent report suggested that several $D B H$ polymorphisms might influence the susceptibility of PD in Eastern India (13). $D B H$ is also known to be a polymorphic gene among different ethnic groups $(14,15,16,17,18,19)$. The contribution of the $D B H$ rs1611115 polymorphism to PD susceptibility has not been investigated previously in Turkish patients. Furthermore, all previous studies in different ethnic groups have been performed more commonly in patients with sporadic PD. In addition to the available results, the present study aimed to be the first to evaluate whether the $D B H$ rs1611115 polymorphism was a potential risk factor for EOPD in the Turkish population.

\section{Materials and Methods}

\section{The Study Cohort}

A total of 114 Turkish patients with EOPD (64 male and 50 female) whose peripheral blood samples were archived under appropriate conditions were retrospectively included in this study. The EOPD diagnosis was made by movement disorder specialists with a standard neurologic examination according to the United Kingdom Neurodegenerative Diseases Brain Bank Criteria (20). All patients were followed-up by the same neurologists between 2011 and 2017. Based on information obtained from patients during the neurologic assessment, family history was considered to be positive for a patient who had a first- or second-degree relative diagnosed with PD previously. Considering that genetic alterations in PARK2, SNCA, PINK1 and DJ1 contribute to EOPD, all patients with EOPD were previously screened for variations in all coding sites and exon-intron boundary regions of these genes (6). The detected variants were analyzed in silico using web-based mutation screening programs. Then, 58 patients ( 32 male and 26 female) who were negative for any variation including pathogenic or non-pathogenic missense, non-sense and/or intronic mutations with unknown significance in any of the genes and whose family history was negative were selected to analyze the effect of the $D B H$ rs1611115 polymorphism on EOPD pathogenesis. For the control group, 58 peripheral blood samples from ethnicity-, sexand age-matched healthy individuals with no known neurologic disorder and no family history of PD were analyzed for the $D B H$ rs1611115 polymorphism. All subjects involved in our study provided written informed consent, and the study was approved by a medical Uludag University Faculty of Medicine Clinical Research Ethics Committee (approvel number: 2017-10/28, date: 04.07.2017). 
Extraction of Genomic DNA from Peripheral Blood Samples

The genomic DNA samples were extracted according to the E.Z.N.A. ${ }^{\circledR}$ Blood DNA Mini Kit (Omega Bio-Tek, Norcross, GA) protocol. The quality and quantity of all DNA samples were determined using a spectrophotometer (Beckman Coulter, Fullerton, CA).

Determination of DBH rs1611115 Polymorphism Frequency

The $D B H$ rs1611115 polymorphism was genotyped using the polymerase chain reaction (PCR)-based restriction fragment length polymorphism (RFLP) method. The primer pairs were designed using the primer designing tool at the National Center for Biotechnology Information web site (https://www.ncbi.nlm. nih.gov/tools/primer-blast/) with the following sequences in the 5' $\rightarrow$ 3' direction: F: GCTGGAGGGATCAAGCAGAAT and R: CAGGACCTTTGCCATCATCCA. The PCR mixture was prepared in a $25 \mu \mathrm{l}$ volume including 10X PCR buffer with $25 \mathrm{mM}$ $\mathrm{MgCl} 2$ solution, $0.2 \mathrm{mM}$ of each dNTP, $0.4 \mu \mathrm{M}$ of each primer, $<0.5 \mu \mathrm{g} / 50 \mu \mathrm{l}$ of genomic DNA, and $1 \mathrm{U}$ HS Prime Taq DNA Polymerase (Genetbio Inc., Korea). The amplification conditions were as follows: Predenaturation for $2 \mathrm{~min}$ at $94^{\circ} \mathrm{C}, 40$ cycles of denaturation for $20 \mathrm{~s}$ at $94^{\circ} \mathrm{C}$, annealing for $45 \mathrm{~s}$ at $60{ }^{\circ} \mathrm{C}$, and elongation for $30 \mathrm{~s}$ at $72{ }^{\circ} \mathrm{C}$, and a final extension for $10 \mathrm{~min}$ at $72{ }^{\circ} \mathrm{C}$. The 129-bp amplicons were digested with FauI (New England Biolabs, Ipswich, MA) restriction endonuclease, and then the digested products were analyzed using 3\% agarose gel electrophoresis. The product containing the $\mathrm{C}$ allele was digested into two fragments of 84-bp and 45-bp, and the undigested 129bp product was accepted to contain the $T$ allele (Figure 1). The RFLP results were also confirmed through DNA sequencing using the GenomeLabTM GeXP Genetic Analysis System (Beckman Coulter, Fullerton, CA) as previously reported (6).

\section{Statistical Analysis}

A Hardy-Weinberg equilibrium (HWE) calculator for biallelic markers (www.oege.org/software/hwe-mr-calc.shtml) was used to determine the genotype frequency of the DBH rs1611115 polymorphism in our study cohort. Mean \pm standard deviation was reported for continuous variables, and frequency was reported for categorical variables. The chi-square $(\chi 2)$ test was used to compare categorical variables with each other and to determine the statistical significance of the distribution of the $D B H$ rs1611115 polymorphisms between the groups. For the comparison of continuous variables in the groups, the independent samples t-test or Mann-Whitney U test was used. All mentioned tests were performed using the IBM SPSS Statistics 23.0 software. A p value of less than 0.05 was considered statistically significant.

\section{Results}

A total of 114 Turkish patients with EOPD (64 males and 50 females) were included in the study. The mean age of onset was $39.98 \pm 7.59$ years and the mean disease duration was $9.77 \pm 7.50$ years. When the genotypic and allelic frequencies of the $D B H$ rs1611115 polymorphism in 114 patients with EOPD were assessed, the CC, CT, and TT genotype frequencies were found as $54.4 \%, 42.1 \%$, and $3.5 \%$, respectively. Thus, the $\mathrm{C}$ and $\mathrm{T}$ allele frequencies were calculated as $75 \%$ and $25 \%$, respectively (HWE $\chi^{2}: 2.12 \mathrm{p}>0.05$ ) (Table 1). Our study group was homogeneous in terms of sex for all the mentioned clinical and genotypic parameters.

Family history was positive in $36 \%(n=41)$ of our patients. The $\mathrm{C}$ allele frequency was slightly lower in the family history-
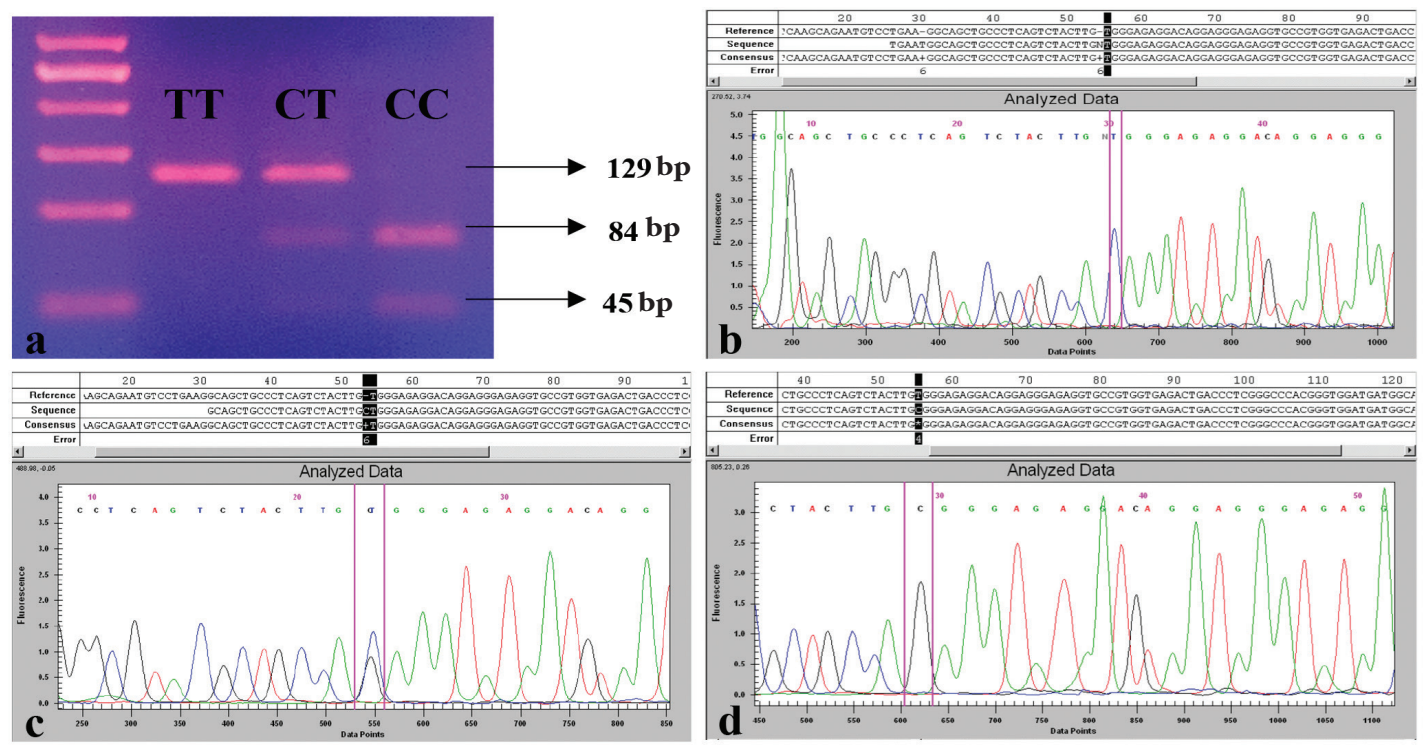

Figure 1. a) RFLP results of the $D B H$ rs1611115 polymorphism with FauI restriction endonuclease treatment. The $\mathrm{C}$ allele was digested into two fragments of $84 \mathrm{bp}$ and $45 \mathrm{bp}$. The undigested $129 \mathrm{bp}$ product was accepted to contain the T allele. The results were confirmed by DNA sequence analysis: b) TT genotype, c) CT genotype, d) CC genotype

RFLP: Restriction fragment length polymorphism, DBH: Dopamine $\beta$-hydroxylase 
positive group than in the negative family history group. However, the difference in the $\mathrm{C}$ allele distribution was not statistically significant $\left(\chi^{2}: 3.53, \mathrm{p}=0.06\right)$ between the two groups (Table 1$)$.

A total of $27.2 \%(n=31)$ of our patients who had any variation including pathogenic or non-pathogenic missense, non-sense and/ or intronic mutations with unknown significance in $E O P D$ genes were grouped as "variation-positive EOPD". Six of these patients had a pathogenic mutation in PARK2 or PINK1, which we have previously reported in detail (6). The presence of variations in $E O P D$ genes was significantly correlated with family history $(\mathrm{p}=0.048)$ but not with the $D B H$ rs1611115 polymorphism $\left(\chi^{2}\right.$ : 1.46, $\mathrm{p}=0.226$ ), as shown in Table 1 .

Finally, $50.8 \% \quad(n=58)$ of our patients were grouped as "variation and family history-negative EOPD". There was no statistically significant difference in the age of onset, duration of disease, sex or allele frequencies of rs 1611115 polymorphisms in this group with the group of 56 patients whose family history was positive or who had a variation in $E O P D$ genes. Thus, we selected these 58 patients to evaluate the effect of only the $D B H$ rs 1611115 polymorphism on EOPD susceptibility that could not be explained by genetic susceptibility and/or family history by comparing the 58 patients with ethnicity-, sex- and age-matched healthy individuals. However, as shown in Table 2, the $\mathrm{C}$ and $\mathrm{T}$ allele frequencies were similar in the EOPD group (C: 78\%; T: 22\%) and the control group (C: 70\%; T: 30\%). Thus, no association was detected between the $D B H$ rs 1611115 polymorphism and EOPD susceptibility in our study group.

\section{Discussion}

The pathogenesis of PD is very complex and is still not completely understood. Studies have reported that the occurrence of PD is correlated with genetic variations and environmental factors. Recently, the influence of genetic factors on PD has been widely studied $(21,22,23,24)$.

$\mathrm{DBH}$, a mixed oxidase, is a biosynthetic enzyme in the catecholamine metabolic system. DBH activity increases when $\mathrm{DBH}$ and noradrenaline are released from sympathetic nerve endings in sympathetic activation. The changes in DBH activity can give rise to abnormal dopamine and noradrenaline metabolic function. Some reports emphasized that SNPs in $D B H$ could change the $\mathrm{DBH}$ activity and reduce the level of dopamine in the brain to influence the occurrence of $\operatorname{PD}(10,15,18)$.

One of these SNPs, rs1611115 $(-1021 \mathrm{C}>\mathrm{T})$, which is a functional promoter polymorphism of $D B H$ at $9 \mathrm{q} 21.1-\mathrm{q} 21.2$ (Figure 2), causes a reduction in plasma $\mathrm{DBH}$ activity and dopamine levels. However, previous studies reported conflicting

Table 1. Genotypic and allelic frequencies of the DBH rs1611115 polymorphism in Turkish patients with EOPD

\begin{tabular}{|c|c|c|c|c|c|c|c|c|}
\hline & \multicolumn{3}{|c|}{$D B H$ rs1611115 genotypes (\%) } & \multicolumn{3}{|c|}{ Allele frequency } & \multirow[b]{2}{*}{ HWE $\chi 2(\mathrm{p})$} & \multirow[b]{2}{*}{ Total } \\
\hline & $\mathrm{CC}(\%)$ & CT $(\%)$ & $\begin{array}{l}\text { TT } \\
(\%)\end{array}$ & Total & $\mathrm{C}$ & $\mathrm{T}$ & & \\
\hline EOPD & $62(54.4)$ & $48(42.1)$ & $4(3.5)$ & 114 & $172(0.75)$ & $56(0.25)$ & $2.12(\mathrm{p}>0.05)$ & 228 \\
\hline Family history- positive EOPD & $17(41.5)$ & $22(53.7)$ & $2(4.9)$ & 41 & $56(0.68)$ & $26(0.32)$ & $2.34(\mathrm{p}>0.05)$ & 82 \\
\hline Family history- negative EOPD & $45(61.6)$ & $26(35.6)$ & $2(2.7)$ & 73 & $116(0.79)$ & $30(0.21)$ & $0.6(\mathrm{p}>0.05)$ & 146 \\
\hline \multicolumn{9}{|c|}{ For TT vs CC, $\chi 2: 0.93 ; \mathrm{p}=0.333$. For CC vs CT + TT, $\chi 2: 3.53 ; \mathrm{p}=0.060$. For T vs C, $\chi 2: 3.52 ; \mathrm{p}=0.060$} \\
\hline *Variation- positive EOPD & $14(45.2)$ & $17(54.8)$ & - & 31 & $45(0.73)$ & $17(0.27)$ & $4.42(\mathrm{p}<0.05)$ & 62 \\
\hline \multicolumn{8}{|c|}{ For CC vs CT + TT, $\chi 2: 1.46 ; \mathrm{p}=0.226$. For $\mathrm{T}$ vs $\mathrm{C}, \chi 2: 0.37 ; \mathrm{p}=0.540$} & 166 \\
\hline
\end{tabular}

Table 2. Genotypic and allelic frequencies of the DBH rs 1611115 polymorphism between both variation and family historynegative EOPD and healthy controls

\begin{tabular}{|c|c|c|c|c|c|c|c|c|}
\hline & \multicolumn{4}{|c|}{ DBH rs1611115 genotypes (\%) } & \multicolumn{4}{|c|}{ Allele frequency } \\
\hline & $\mathrm{CC}(\%)$ & $\mathrm{CT}(\%)$ & TT (\%) & Total & $\mathrm{C}$ & $\mathrm{T}$ & HWE $\chi 2(p)$ & Total \\
\hline $\begin{array}{l}\text { Variation and family } \\
\text { history- negative } \\
\text { EOPD }\end{array}$ & $35(60.3)$ & $21(36.2)$ & $2(3.4)$ & 58 & $91(0.78)$ & $25(0.22)$ & $0.29(p>0.05)$ & 116 \\
\hline Control group & $26(44.8)$ & $29(50.0)$ & $3(5.2)$ & 58 & $81(0.70)$ & $35(0.30)$ & $2.02(\mathrm{p}>0.05)$ & 116 \\
\hline \multicolumn{9}{|c|}{ For TT vs. CC, $\chi 2: 0.56 ; p=0.451$. For CC vs CT + TT, $\chi 2: 2.80 ; p=0.094$. For T vs C, $\chi 2: 2.24 ; p=0.133$} \\
\hline \multicolumn{9}{|c|}{ DBH: Dopamine $\beta$-hydroxylase, EOPD: Early-onset Parkinson's disease, $\chi 2$ : Chi-square, HWE: Hardy-Weinberg equilibrium } \\
\hline
\end{tabular}




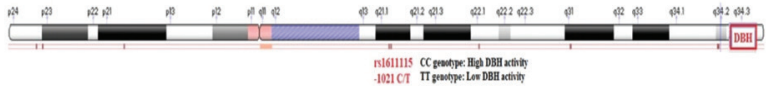

Figure 2. A schematic representation of the $D B H$ gene on chromosome 9. The location of the rs1611115 (-1021 C/T) is also shown at 9q21.1-q21.2. The genotypes of the rs 1611115 , CC or TT, indicates related enzyme activity. The figure that is modified is also available at: https://www.ncbi. nlm.nih.gov/variation/view/?q=rs1611115\&assm=GCF_000001405.38

DBH: Dopamine $\beta$-hydroxylase

associations between PD and DBH polymorphisms. The functional -1021CT polymorphism in the $D B H$ gene has been demonstrated to regulate plasma $\mathrm{DBH}$ activity, and individuals who have genetically determined TT genotypes with low serum DBH activity are protected against PD (15). Similarly, Ghosh et al. (18) analyzed three reported SNPs, rs1611115 (C>T), rs1108580 $(\mathrm{A}>\mathrm{G})$, and rs129882 $(\mathrm{C}>\mathrm{T})$, of the $D B H$ gene in Indian patients with PD and reported a significant correlation between plasma $\mathrm{DBH}$ activity and the rs1611115 polymorphism. Additionally, the representation of the $\mathrm{T}$ allele was statistically significant in control samples in this study. A recent report suggested that several $D B H$ polymorphisms might influence the susceptibility of PD in Eastern India (13). Shao et al. (19) also found that the $D B H$ rs1611115 polymorphism, but not rs732833, was likely to be associated with the susceptibility to PD in the Han population. However, Chun et al. (16) suggested that the DBH rs1611115 polymorphism was not significantly associated with the risk of PD. In addition, Ross et al. (17) reported that DBH $-1021 \mathrm{C}>\mathrm{T}$ (rs1611115) did not play a major role in the pathogenesis of PD. Similarly, Kang et al. (12) suggested that the DBH rs1611115 genetic polymorphism might not be associated with PD in Asia or Europe. In the present study, we examined the $D B H$ rs1611115 polymorphism in a sample of Turkish patients with EOPD by comparing ethnically and age-matched control subjects. There was no significant difference in the genotypic and allelic frequencies of $D B H$ rs1611115 between the two patient groups.

\section{Conclusion}

It is noteworthy that this is the first report to evaluate the $D B H$ rs1611115 polymorphism in patients with EOPD and ethnically matched controls in the Turkish population. Although previous studies reported conflicting associations between the functional $D B H$ rs1611115 polymorphism and PD pathogenesis, our results show that there is no effect of the $D B H$ rs1611115 polymorphism on EOPD susceptibility. However, the main limitation of this study was the small sample size of 114 patients. Thus, further studies should focus on the other dopamine metabolism-related genetic variants as well as $D B H$ rs1611115 in larger study cohorts.

Ethics

Ethics Committee Approval: Uludag University Faculty of Medicine Clinical Research Ethics Committee (approvel number: 2017-10/28, date: 04.07.2017).

Informed Consent: All subjects involved in our study provided written informed consent.

Peer-review: Externally and internally peer-reviewed.

\section{Authorship Contributions}

Surgical and Medical Practices: S.E., B.Ç., A.B.T., E.S., M.D., C.A., M.Z., O.D., H.K., G.K., R.Ç., B.E., Concept: S.E., I.E.E., Ü.E., G.Ç., B.T., M.Z., Design: S.E., I.E.E., Ü.E., G.Ç., M.Z., Data Collection or Processing: I.E.E., D.K.Ç., E.K., Analysis or Interpretation: S.E., I.E.E., Ü.E., G.Ç., Literature Search: S.E., I.E.E., D.K.Ç., Writing: S.E., I.E.E.

Conflict of Interest: No conflict of interest was declared by the authors.

Financial Disclosure: Bursa Uludag University Scientific Research Projects Unit HDP (T) was supported by the project no: $2017 / 39$.

\section{References}

1. De Rijk MC, Tzourio C, Breteler MM, et al. Prevalence of parkinsonism and Parkinson's disease in Europe: the Europarkinson Collaborative Study: European community concerted action on the epidemiology of Parkinson's disease. J Neurol Neurosurg Psychiatry 1997;62:10-15.

2. Dauer W, Przedborski S. Parkinson's disease: mechanisms and models. Neuron 2003;39:889-909.

3. De Lau LM, Breteler MM. Epidemiology of Parkinson's disease. Lancet Neurol 2006;5:525-535.

4. Lücking CB, Dürr A, Bonifati V, et al. French Parkinson's disease genetics study group; European consortium ongenetic susceptibility in Parkinson's disease. association between early-onset Parkinson's disease and mutations in the Parkin gene. N Engl J Med 2000;342:1560-1567.

5. Eriksen JL, Wszolek Z, Petrucelli L. Molecular pathogenesis of Parkinson disease. Arch Neurol 2005;62:353-357.

6. Erer S, Egeli U, Zarifoglu M, et al. Mutation analysis of the PARKIN, PINK1, DJ1, and SNCA genes in Turkish early-onset Parkinson's patients and genotype phenotype correlations. Clin Neurol Neurosurg 2016;148:147-153

7. Eryilmaz IE, Cecener G, Erer S, et al. Epigenetic approach to early-onset Parkinson's disease: low methylation status of SNCA and PARK2 promoter regions. Neurol Res 2017;39:965-972.

8. La Cognata V, Morello G, D'Agata V, Cavallaro S. Copy number variability in Parkinson's disease: Assembling the puzzle through a systems biology approach. Hum Genet 2017;36:13-37.

9. Rush RA, Geffen LB. Dopamine beta-hydroxylase in health and disease. Crit Rev Clin Lab Sci 1980;12:241-277.

10. Zabetian CP, Buxbaum SG, Elston RC, et al. The structure of linkage disequilibrium at the $\mathrm{DBH}$ locus strongly influences the magnitude of association between diallelic markers and plasma dopamine beta-hydroxylase activity. Am J Hum Genet 2003;72:1389-1400.

11. Tunbridge EM, Narajos $\mathrm{M}$, Harrison $\mathrm{CH}$, et al. Which Dopamine Polymorphisms Are Functional? Systematic Review and Meta-analysis of COMT, DAT, DBH, DDC, DRD1-5, MAOA, MAOB, TH, VMAT1, and VMAT2. Biol Psychiatry 2019;86:608-620.

12. Kang S, Bi M, Du X, et al. Association of the rs1611115 polymorphism in DBH gene with Parkinson's disease: a meta-analysis. Neurol Sci 2018;39:2085-2089.

13. Ghosh A, Sadhukhan T, Giri S, et al. Dopamine $\beta$ Hydroxylase (DBH) is a potential modifier gene associated with Parkinson's disease in Eastern India. Neurosci Lett 2019;27:75-80.

14. Zabetian CP, Anderson GM, Buxbaum SG, et al. A quantitative-trait analysis of human plasma dopamine beta-hydroxylase activity: Evidence for a major functional polymorphism at the DBH locus. Am J Hum Genet 2001;68:515-522.

15. Healy DG, Abou-Sleiman PM, Ozawa T, et al. A functional polymorphism regulating dopamine beta-hydroxylase influences against Parkinson's disease. Ann Neurol 2004;55:443-446.

16. Chun LS, Samii A, Hutter CM, et al. DBH -1021C--> T does not modify risk or age at onset in Parkinson's disease. Ann Neurol 2007;62:99-101.

17. Ross OA, Heckman MG, Soto AI, et al. Dopamine beta-hydroxylase $-1021 \mathrm{C}>\mathrm{T}$ association and Parkinson's disease. Parkinsonism Relat Disord 2008;14:544-547. 
18. Ghosh A, Biswas A, Sadhukhan T, et al. Role of dopamine $\beta$ Hydroxylase $(\mathrm{DBH})$ in Parkinson's disease patients of Indian population. Mol Cytogenet 2014;7(Suppl 1):P122. Published online 2014 Jan 21.

19. Shao P, Yu YX, Bao JX. Association of dopamine beta-hydroxylase (DBH) polymorphisms with susceptibility to Parkinson's disease. Med Sci Monit 2016;22:1617-1622.

20. Hughes AJ, Daniel SE, Kilford L, et al. Accuracy of clinical diagnosis of idiopathic Parkinson's disease: a clinico-pathological study of 100 cases. J Neurol Neurosurg Psychiatry 1992;55:181-184.

21. Magrinelli F, Picelli A, Tocco P, et al. Pathophysiology of motor dysfunction in Parkinson's disease as the rationale for drug treatment and rehabilitation. Parkinsons Dis 2016;2016:9832839.
22. $\mathrm{Xu} \mathrm{L}, \mathrm{Pu}$ J. Alpha-synuclein in Parkinson's disease: From pathogenetic dysfunction to potential clinical application. Parkinsons Dis 2016;2016:1720621.

23. Ehgoetz Martens KA, Lewis SJ. Pathology of behavior in PD: What is known and what is not? J Neurol Sci 2017;374:9-16.

24. Zhang PL, Chen Y, Zhang $\mathrm{CH}$, et al. Genetics of Parkinson's disease and related disorders. J Med Genet 2018;55:73-80. 